\title{
DINAMIKA PERKEMBANGAN MUSIK GAMBANG KROMONG BETAWI
}

\author{
Sukotjo \\ Jurusan Etnomusikologi FSP ISI Yogyakarta \\ Email:sukotjo068@gmail.com
}

\begin{abstract}
Abstrak
Musik gambang kromong yang berkembang dalam masyarakat etnis Betawi di Jakarta mengalami suatu perkembangan dengan menyesuaikan dari dinamika masyarakatnya. Hal itu disesuaikan dengan keinginan masyarakatnya dalam mengapresiasi musik tersebut dalam siklus kehidupan yang dijalaninya. Perkembangan tersebut menimbulkan dua penyebutan dalam musik Gambang Kromong yaitu musik Gambang Kromong Asli dan Musik Gambang Kromong Kombinasi. Melihat dari perubahan yang terjadi sebagai suatu kasus dalam rentang waktu tertentu maka pembahasan permasalahan tersebut dikaji dari perisitwa sejarahnya secara sinkronik yang mengambil dari fase sebelum Indonesia merdeka sampai setelah merdeka, sehingga metode penelitian mempergunakan studi kasus. Hasil penelitian yang didapat adalah adanya sebuah perkembangan yang cukup signifikan dalam ensambel Gambang Kromong baik dari musikologis maupun instrumentasinya.
\end{abstract}

Keyword : Dynamics, Gambang Kromong Music, Development

\begin{abstract}
Gambang Kromong music that developed in the Betawi ethnic community in Jakarta experienced a development by adjusting to the dynamics of the community. This is adjusted to the wishes of the community in appreciating the music in the cycle of life they live. This development gave rise to two mentions of Gambang Kromong music, namely the Original Gambang Kromong music and the Combination Gambang Kromong music. Seeing from the changes that occurred as a case in a certain time span, the discussion of these problems was studied from historical events synchronously which took from the phase before Indonesia's independence until after independence, so the research method used case studies. The result of the research is that there is a significant development in the Gambang Kromong ensemble, both in terms of musicology and instrumentation.
\end{abstract}

Keyword: Dinamika, Musik Gambang Kromong, Perkembangan.

\section{A. Pendahuluan}

Jakarta sebagai pusat ibukota negara

Indonesia berkembang demikian pesatnya seiring dengan dinamika perkembangan zamannya. Sebagai ibukota negara Indonesia, Jakarta banyak dikunjungi oleh para pendatang baik dari domestik maupun manca negara. Sejak zaman penjajahan sampai dengan kemerdekaan Republik Indonesia tanggal 17 Agustus 1945, masyarakat yang mendiami kota Jakarta terdiri dari berbagai multi etnis. Dalam memahami kebudayaan Jakarta yang dihubungkan sebagai produk 
sejarah, maka yang harus diperhatikan yaitu sejarah masyarakatnya dan produk yang dihasilkan yang berupa pedoman bagi orang Jakarta dalam kehidupannya (Suparlan, 2004: 141). Masyarakat Jakarta yang beranekaragam (heterogen) sejak zaman penjajahan sampai kemerdekaan mempunyai suatu penduduk pribumi yang dinamakan masyarakat atau orang Betawi. Masyarakat ini merupakan produk sejarah dari perjalanan sebuah kota dengan berbagai macam pola kehidupan.

Masyarakat Betawi yang mendiami daerah Jakarta tidak lepas dari sejarah kerajaan Hindu-Jawa pada abad ke-12 yang bernama Pajajaran yang menguasai Bandar pelabuhan di Banten dan Sunda Kalapa. Pada saat itu pusat kerajaan berada di daerah Bogor (daerah selatan Jakarta) yang mempunyai kontur geografis pegunungan dengan aliran sungai Ciliwung sebagai transportasi penghubungnya. Nama pelabuhan tersebut diambil dari dua suku kata yaitu Sunda dan Kalapa. Sunda yang dimaksudkan adalah suatu masyarakat yang mendiami daerah tersebut yang memakai bahasa Sunda sebagai bahasa pengantarnya, sedangkan kata Kalapa diambil dari tumbuhan atau pohon kelapa yang banyak menaungi pelabuhan tersebut. Pada tanggal 21 Agustus 1522 penguasa Sunda Kalapa (kerajaan Pajajaran) membuat perjanjian dengan bangsa Portugis yang mulai mengadakan eksvansinya ke pulau Jawa. Raja Pajajaran yang bernama Surawisesa (Samiam) mengadakan perjanjian dengan bangsa Portugis yang diwakili oleh Henrique Leme dengan disaksikan oleh tiga orang pembantu raja yang bernama Mandari Tada (mantri dalem), Tamungo Sangue de Pate (tumenggung sang adipati), dan Bengar (adipati). Perjanjian tersebut berisi tentang pertukaran sejumlah lada dengan barangbarang dari Portugis serta diperkenankannya Portugis untuk membangun benteng di Sunda Kalapa. Kerajaan Pajajaran juga meminta bantuan kepada Portugis dari ancaman kerajaan Demak. Hasil dari perjanjian tersebut dibuatkan Padrau (tugu batu) di tepi sungai ciliwung (Hoesein, 1983: 81).

Jakarta yang dikenal dengan nama Batavia pada zaman penjajahan (abad XVII) merupakan tempat pertemuan antar berbagai budaya yang dibawa oleh para pendatang. Akulturasi yang terjadi dengan adanya para pendatang tersebut menjadikan sebuah komunitas tersendiri dari masyarakat Jakarta. Percampuran penduduk multi etnis itu memberikan suatu nuansa dari kehidupan kota Batavia yang heterogen. Dalam perkembangannya (abad XIX) terjadilah sebuah perpaduan antar masyarakat yang ada di Batavia dengan suatu melting pot antar etnis yang berasal dari nusantara dan mancanegara sehingga menjadikan suatu kelompok etnis yang mempunyai ciri khas. Masyarakat etnis tersebut menamakan komunitasnya dengan sebutan orang atau masyarakat Betawi (Castle, 
1967: 153 - 204). Orang atau masyarakat Betawi sebagian besar bermukim di daerah Jakarta dan merupakan masyarakat pribumi kota tersebut. Secara sosio-kultural masyarakat Betawi mempunyai peranan tersendiri dalam mengemban norma-norma sosial dan keagamaannya. Dengan demikian Betawi merupakan nama yang dimaksudkan untuk menunjuk suatu kebudayaan.

Masyarakat Betawi yang sudah lama mendiami kota Jakarta mempunyai adat istiadat dan pola hidup yang khas. Sebagian besar masyarakat Betawi menganut agama Islam, kecuali orang Cina Benteng (peranakan orang Betawi dengan orang Cina). Dalam hal berkesenian, masyarakat Betawi mempunyai sebuah musik tradisional yang dinamakan Gambang Kromong. Secara etimologi Gambang Kromong berasal dari penyebutan alat musik yang dipergunakan yaitu Gambang dan Kromong. Sebuah ensambel Gambang Kromong terdiri dari alat musik Gambang, Kromong, Sukong, Tebyan, Kongabyan, Basing/suling, Ningnong, Jutao, Kecrek, Kempul, dan Gong. Musik Gambang Kromong yang sudah dikenal pada tahun 1880 pada waktu Bek Teng Tjoe (seorang kepala kampung atau wilayah pada saat itu) menyajikan musik tersebut untuk sebuah sajian penyambutan para tamunya (Poa, 1949: 39).

Ensambel musik ini berkembang di kalangan masyarakat Cina Benteng. Hal itu dikarenakan masyarakat tersebut dalam hal kehidupannya (segi materi) dapat terpenuhi, sehingga untuk mengadakan perjamuan tamu kerap kali mengadakan suatu sajian musik Gambang Kromong (Muhadjir, et al., 1986, $13-14)$.

Musik Gambang Kromong yang berfungsi sebagai penyemarak ritual untuk acara perkawinan, sunatan, kaul/nazar, dan lain-lain dalam masyarakat Betawi, mendapat suatu peluang yang dipergunakan untuk kepentingan pariwisata. Penggunaan musik ini sebagai sajian pariwisata mendapat dukungan dari para seniman pendukungnya. Kurangnya intensitas penyajian musik tersebut yang dilakukan oleh masyarakat Betawi dalam mengadakan kegiatannya dapat ditopang dengan kegiatan program paket penyajian pariwisata. Hal itu berkaitan dengan faktor pendapatan dalam keberlangsungan sebuah grup musik ini.

\section{Perkembangan Musik Gambang Kromong}

Musik Gambang Kromong muncul seiring dengan perkembangan masyarakat Betawi di Jakarta. Orang Betawi merupakan sebuah masyarakat yang terbentuk dari akulturasi berbagai suku yang mendiami pelabuhan Sunda Kalapa yang terakumulasi menjadi identitas yang dinamakan orang Betawi pada abad ke-19. Hal itu dikarenakan Sunda Kalapa merupakan pelabuhan dan 
pusat kehidupan politik, perdagangan dan kehidupan sosial lainnya.

Menurut Poan Kian Sioe, musik Gambang Kromong merupakan perpaduan antara ensambel musik Yang Khim (orang Cina) dengan peralatan musik tradisional pribumi. Adapun ensambel Yang Kim dimainkan dengan mempergunakan alat musik Yang Khim, Sukong, Hosiang, Thehian, Kongahian, Sambian, Suling, Pan (sejenis Kecrek), dan Ningnong. Akulturasi budaya yang terjadi antara orang Cina dengan orang pribumi yaitu munculnya musik Gambang Kromong. Perpaduan itu menghilangkan alat musik Yang Kim yang digantikan dengan alat musik Gambang, serta alat musik Sambian dan Hosiang tidak dipergunakan lagi. Pada tahun 1880 seorang pemusik yang bernama Tan Wangwe dengan pengesahan seorang pemimpin (Bek) orang Cina di kawasan Pasar Senen yang bernama Teng Tjoe, melengkapi musik Gambang Kromong dengan instrument Kromong, Gendang, Kempul dan Gong. Selain itu dibawakan pula lagu Sunda popular dalam sajiannya (Phoa, 1949, 20).

Musik Gambang Kromong yang berkembang dalam masyarakat Betawi di Jakarta disajikan menurut pesanan yang dikehendaki oleh masyarakatnya. Musik merupakan sebuah produk yang mempunyai konsep dalam pembuatannya "Music is product of a man and has a structure buts is structure cannot have a existence of its own divorced from the behavior produces if' (Merriam, 1964: 7). Sebagai produk masyarakat musik tradisional yang berkaitan dengan filosofis yang berkembang di masyarakat etnis. Varian yang terjadi dari produk masyarakat tersebut bermacammacam sehingga menimbulkan suatu bentuk gaya.

Musik Gambang Kromong yang berada dalam masyarakat Betawi merupakan perpaduan antara beberapa kebudayaan yang saling mengadakan interaksi (akulturasi). Hal ini dapat terlihat dari beberapa instrumen yang digunakan dalam ensambel tersebut, misalnya: instrumen gesek dan tiup dari Cina, instrumen gendang dari Sunda, dan instrumen gambang, kromong, kempul, kecrek, serta gong dari Jawa. Warna musik yang ditampilkan merupakan hasil asimilasi dari tangga nada pentatonis dan diatonis. Musik ini dalam meregenerasikan untuk para penerusnya dengan cara transmisi dari para senior kepada para juniornya, hal itu dikarenakan musik ini tergolong jenis musik yang non literate (tidak mempunyai sistem penotasian).

Musik Gambang Kromong dapat dipadukan dengan sebuah jenis teater Betawi yang dinamakan Lenong. Peran ensambel musik tersebut dalam penyajian Lenong berguna sebagai pengisi suasana dan pengiring untuk penyajiannya. Musik ini sudah dikenal pada tahun 1880 pada waktu Bek Teng Tjoe menyajikan musik tersebut untuk sebuah 
sajian penyambutan para tamunya. Ensambel musik ini berkembang di kalangan masyarakat Cina Benteng. Hal itu dikarenakan masyarakat tersebut dalam hal kehidupannya (segi materi) dapat terpenuhi, sehingga untuk mengadakan perjamuan tamu kerap kali mengadakan suatu sajian musik Gambang Kromong. Masyarakat Betawi mempergunakan musik Gambang Kromong sebagai sebuah sajian untuk hiburan dan penyemarak upacara ritual.

Masyarakat Betawi dalam dinamika kota Jakarta yang demikian pesat banyak dipengaruhi oleh beberapa bentuk musik yang berkembang (seperti: pop, dangdut, dan keroncong). Masyarakat pendukung yang mengapresiasi bentuk musik tersebut menginginkan musik Gambang Kromong dapat mentransfromasikannya kedalam repertoarnya. Musik yang menjadi sebuah simbol ketenaran ditransformasikan ke dalam ensambel Gambang Kromong secara paksa dalam menunjang selera penonton. Lagu-lagu yang dialihkan dari musik populer membuat suatu perubahan dalam segi instrumentasinya (alat-alat musik yang dipergunakan).

Faktor komersial yang menjadikan bentuk musik Gambang Kromong bergeser dalam hal penyajiannya merupakan suatu keadaan yang nyata dari penyesuaian sebuah bentuk musik tradisional dengan perkembangan zamannya. Penambahan yang terjadi di dalam sebuah repertoar musik Gambang Kromong memberikan sebuah perbedaan dari orisinalitas musik tersebut. Lagu-lagu tradisi, seperti: Cente Manis, Kramat Karem, Balo-balo, Sirib Kuning, Jali-jali, dan lainlain, sudah semakin tergusur keberadaannya dengan dimasukkannya beberapa repertoar lagu dangdut, pop, dan keroncong. Volume penyajian tentang lagu-lagu tradisional sudah semakin menyusut.

Musik Gambang Kromong Betawi di Jakarta-pun telah mengarah pada pola hidup modern. Masyarakat pendukung yang dipengharuhi oleh beragam musik hiburan membawa dampak terhadap perkembangan musik Gambang Kromong. Untuk memenuhi tuntutan para pendukung tersebut musik Gambang Kromong harus menyesuaikan diri dengan dinamika masyarakat. Musik Gambang Kromong Betawi asli menggunakan sistem nada pentatonis (lima nada) dan kalimat-kalimat syair lagu dalam bentuk pantun. Pola musik seperti ini merupakan ciri khas musik Gambang Kromong asli. Yang sudah berlangsung lama secara turun temurun.

Dalam perkembangannya terdapat dua pengertian musik Gambang Kromong Betawi yaitu musik Gambang Kromong asli dan musik Gambang Kromong kombinasi. Musik Gambang Kromong asli masih mempergunakan instrumen tradisional, sedangkan musik Gambang Kromong kombinasi telah menambahkan alat-alat musik Barat kedalamnya. Instrumen Barat yang 
ditambahkan antara lain gitar, bass listrik, keyboard, saxopon, biola dan terompet. Keterangan yang akan diberikan tentang pengaruh instrumen Barat terhadap musik Gambang Kromong akan ditinjau dari segi musikologisnya. Sejauhmana pengaruh penggunaan instrumen Barat diatonis terhadap musik Gambang Kromong yang bersistem nada pentatonis.

Sikap artistik masyarakat pendukung yang mendominasi perkembangan musik Gambang Kromong memberikan suatu dinamika tersendiri di dalam ensambel musik ini. Adanya keragaman kesenangan dari beberapa jenis musik yang diapresiasikan dalam masyarakat membuat berbagai penyesuaian pada musik Gambang Kromong dalam penyajiannya.

\section{Perpaduan Instrumen Barat dan Etnis Dalam Musik Gammbang Kromong}

Masyarakat Betawi berkembang seiring dengan perkembangan zaman yang mempengaruhi pola kehidupan. Arus modernisasi yang berkembang demikian pesatnya telah mempengaruhi keberadaan musik Gambang Kromong dalam masyarakat Betawi. Digunakannya beberapa instrumen Barat di dalam ensambel musik tersebut merupakan sebuah contoh. Penyebutan Gambang Kromong diambil dari nama alat musik yang dipergunakan dalam ensambel tersebut yaitu Gambang dan Kromong.
Jakarta yang merupakan pusat ibukota sejak bernama Batavia sudah menjadi tempat pertemuan antara beberapa budaya yang dibawa oleh para pendatang. Interaksi antara beberapa kesenian etnis yang ada di jakarta merupakan ciri khas dari musik Gambang Kromong Betawi.

Musik gambang kromong mempunyai karakter dalam sajiannya. Sebagai suatu genre musik yang memiliki ciri khas tersebut, maka musik itu mempunyai konsep musik yang jelas. Hal itu dipertegas dengan konsep musik yang dianggap penting oleh Merriam yaitu konsep dalam hal praktek dan pertunjukan music itu serta produksi dari suara musik, yang dikatakannya: " one of the most important of such concet is the distinction, implied or real, made between music on the one hand, and noise, or non-music, on the other; this his the basic to understanding of music in any society" (Merriam, 1964, 63).

Musik Gambang Kromong asli yang menggunakan instrumen tradisional, seperti sukong, tehyan, kongabyan, basing, jutao, gambang, kromong, gendang kempul, ningnong, dan gong, sudah mengkristal dalam kehidupan masyarakat Betawi. Perkembangan zaman melahirkan ensambel baru yang bernama musik Gambang Kromong kombinasi dengan penambahan instrumen musik Barat. Hal itu dilakukan untuk memenuhi tuntutan masyarakat pendukung yang menginginkan lagu-lagu yang populer dalam masyarakat 
dimainkan dalam oleh ensambel musik Gambang Kromong.

Selain penggunaan alat musik Barat, perbendaharaan lagu Gambang Kromong menyesuaikan dengan perkembangan lagu populer di masyarakat. Pada waktu masyarakat suka lagu Jaipongan, maka lagu-lagu Gambang Kromong didominasi lagu-lagu Jaipongan, demikian juga ketika masyarakat menggemari lagu pop, keroncong, dan dangdut. Walaupun lagu-lagu tersebut masuk dalam perbendaharaan musik Gambang Kromong, tetapi ada upaya dari para pemain musiknya untuk tetap membawakan lagu dalem, seperti Kramat Karem, Cente Manis, Jali-jali, Sirih Kuning, Balo-balo, dan lain-lain. Masuknya lagu-lagu tersebut tidak dapat dihindari karena masyarakat pendukung musik Gambang Kromong dapat menerima dan memberikan jalan bagi masuknya lagulagu tersebut.

\section{Ensambel Gambang Kromong} merupakan musik tradisional yang non literate (tidak memiliki sistem penotasian). Musik ini mempergunakan tangga nada pentatonis (lima nada) sebagai nada pokok yang dipergunakan dalam pola permainan musiknya. Alat musik yang menjadi tolok ukur dari nada pokok (dasar) yang dipergunakan terdapat pada instrumen Gambang dan Kromong. Adapun urutan tangga nada tersebut apabila diukur dengan auto chromatic chord (sebagai contoh diambil dari instrumen gambang dan kromong yang dipergunakan dalam grup Selendang Betawi), maka dapat didekatkan dengan penggunaan notasi diatonis (solmisasi) yaitu D (re), E (mi), F\# (fis), G (sol), dan A (la). Lima nada pokok yang dipergunakan dalam ensambel Gambang Kromong menjadikan musik tersebut mempunyai ciri khas dari segi permainannya. Adapun jarak nadanya (interval) dari D ke E, E ke F\#, dan A ke B merupakan sekonde besar, sedangkan jarak nada F\# ke A merupakan interval terts kecil. Walaupun dapat dimainkan dengan alat musik diatonis, tetapi tangga nada yang dipergunakan dalam hal loncatan nadanya (interval) sangat berbeda. Harmonisasi yang terjadi dalam jalinan nadanya dapat memberikan warna suara khas dari musik Gambang Kromong. Adapun tangga nada yang terdapat dalam ensambel Gambang Kromong adalah sebagai berikut: 


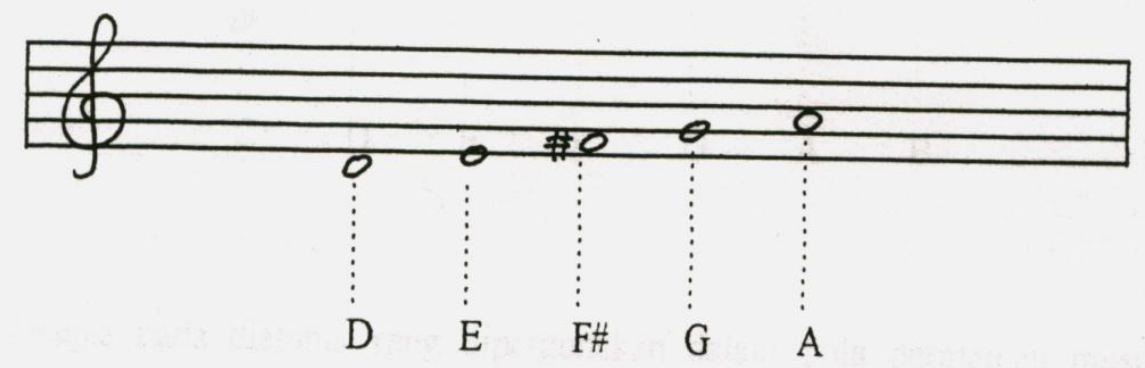

Gambar 1

Tangga Nada Gambar Kromong

Masuknya alat musik Barat dalam ensambel

Gambang Kromong membuat musik

tersebut harus menyesuaikan dengan

penggunaan tangga nada diatonis (tujuh

nada) pada pola permainannya. Adapun urutan nada pokok diatonis yang dipergunakan dalam pola permainan tersebut adalah C (do), D (re), E (mi), F (fa), G (sol), A (la), dan B (si).

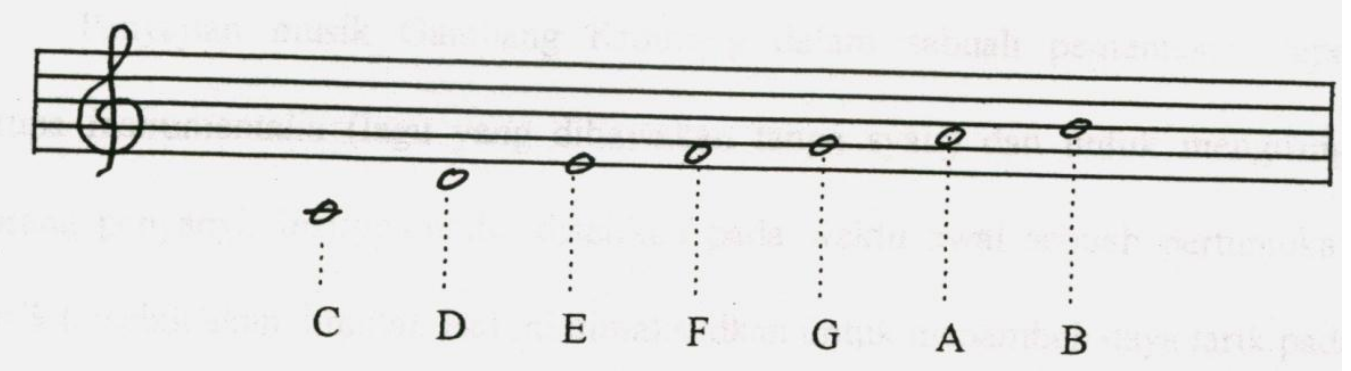

Gambar 2

Perkembangan tangga nada pada Gambang Kromong

Tangga nada diatonis yang dipergunakan dalam pola permainan musik tersebut membuat bergesernya aturan-aturan yang menjadi suatu patokan (patron) dalam pola permainannya. Instrumen Gambang dan Tebyan yang menjadi alat musik pembuka (introduksi) pada setiap sajian musik Gambang Kromong kedudukannya tergeser dengan penggunaan alat musik Barat ke dalam ensambel tersebut. Gitar elektrik dan Saxopone yang merupakan instrumen Barat, lebih mendominir dalam sajian yang dimainkan.

Dinamika perubahan tangga nada, dan masuknya alat musik Barat dalam seni Gambyang Kromong memberikan dampak tidak hanya pada akulturasi saja, tetapi juga komodifikasi budaya. Hal ini sekaligus 
menjadi permasalahan, tantangan bagi eksistensi Gambang Kromong di era modernitas.

\section{Latens Manifest}

Malinowsky (dalam kontjaraningrat; 1987; Ohi, 2014) menjelaskan bahwa segala sesuatu yang ada didunia memiliki fungsi. Fungsi berarti memiliki kontribusi yang dapat diberikan oleh sesuatu kepada yang lain. Segala aktivitas kebudayaan merupakan suatu rangkaian dari habitus manusia dalam memenuhi kebutuhan nalurinya. Sebab akibat pada aktifitas biasanya terjadi karena kombinasi dari berbagai macam kebutuhan manusia.

Kebutuhan manusia tersebut pada akhirnya melahirnya suatu idiom baru yaitu latensmanifest kedudukan suatu ihwal kebudayaan termasuk kesenian. Merton (dalam Kaplan Manners , 2002) menjelaskan tentang postulat keutuhan fungsional baik masyarakat ataupun secara universal. Secara empiric sebuah keutuhan fungsional merupakan relasi antara fungsionaldisfungsional seperti simbiosis mutualisme komplementer, dimana fungsional mampu memelihara keterpiaraan sebuah sistem sedangkan disfungsiona akan menghasilkan resistensi, tekanan yang mengancam eksistensi sistem. Perkembangan dari relasi fungsional-disfungsional tersebut maka
Merton menjelaskan mengenai konse latensmanifest (fungsi terselubung dan fungsi tampak). Fungsi manifest adalah konsekuensi obyektif yang memberikan sumbangan pada penyesuaian atau adaptasi sistem yang dikehendaki, disadari oleh masyarakat selaku pemilik kebudayaan sedangkan fungsi latens adalah konsekuensi obyektif dari suatu ihwal budaya yang tidak dikehendaki maupun disadari oleh warga masyarakat yang berdampak terhadap punahnya sebuah kebudayaan. Konsep latens-manifest dalam aktifitas kebudayaan termasuk kesenian mampu berlaku bolak balik bergantung dari masyarakat

\section{B. Metode Penelitian}

Kasus perkembangan dinamika musik Gambang Kromong secara kronologis selalu berhubungan dengan sejarah, masuknya instrumen musik Barat merupakan sebuah proses yang mempunyai nilai positif seperti adanya akulturasi, transformasi dan komodifikasi tetapi sudut pandang lain juga terdapat nilai negatif seperti menurunkan nilai identitas karena adanya latens-manifest dari kedudukan musik Gambang Kromong pada aktivitas kebudayaan masyarakat. Berdasarkan hal tersebut maka dalam penelitian ini menggunakan studi kasus. Cresswell (2011, 20) menjelaskan bahwa studi kasus merupakan strategi penelitian 
dimana didalamnya peneliti menyelidiki secara cermat suatu program, peristiwa, aktivitas, proses atau sekelompok individu. Kasus-kasus dibatasi oleh waktu dan aktivitas, dan peneliti mengumpulkan informasi secara lengkap dengan menggunakan berbagai prosedur pengumpulan data berdasarkan waktu yang telah ditentukan.

Pengumpulan data penelitian ini mempergunakan studi literatur, fieldwork, dan dokumentasi sedangkan analisis data mempergunakan struktur domain. Studi literatur merupakan sebuah teknik pengumpulan data berdasarkan sumber tertulis. Studi literatur adalah serangkaian kegiatan yang berkenaan dengan metode pengumpulan data pustaka, membaca dan mencatat, serta mengelolah bahan penelitian. Menurut Danial dan Warsiah (2009:80), Studi Literatur adalah merupakan penelitian yang dilakukan oleh peneliti dengan mengumpulkan sejumlah buku buku, majalah yang berkaitan dengan masalah dan tujuan penelitian. Teknik ini dilakukan dengan tujuan untuk mengungkapkan berbagai teoriteori yang relevan dengan permasalahan yang sedang dihadapi atau diteliti sebagai landasan dalam pembahasan hasil penelitian. Pengertian lain tentang Studi literatur adalah mencari referensi teori yang relefan dengan kasus atau permasalahan yang ditemukan. Secara Umum Studi Literatur adalah cara untuk menyelesaikan persoalan dengan menelusuri sumber-sumber tulisan yang pernah dibuat sebelumnya. Dengan kata lain, istilah Studi Literatur ini juga sangat familier dengan sebutan studi pustaka. Dalam sebuah penelitian yang hendak dijalankan, tentu saja seorang peneliti harus memiliki wawasan yang luas terkait objek yang akan diteliti. Jika tidak, maka dapat dipastikan dalam persentasi yang besar bahwa penelitian tersebut akan gagal.

Studi literatur yang dilakukan pada penelitian ini adalah melakukan pencarian artikel, dokumentasi tentang musik Gambang Kromong sebelum era kemerdekaan dan sesudah kemerdekaan, kemudian data tersebut dipilah.

Fieldwork dalam konsep etnomusikologi adalah langkah-langkah untuk mengumpulkan berbagai data yang diperlukan, seperti menentukan informan, lokasi, dan wawancara (Moistoforoy, 2002). Teknik yang dilakukan adalah wawancara dengan informan dari grup Gambang Kromong.

Analisis Data dilakukan dengan 4 tahapan yaitu pengumpulan data, reduksi data, penyajian data dan penarikan kesimpulan:

1. Pengumpulan data adalah sebuh teknik yang berfungsi untuk mengumpulkan data-data baik primer 
ataupun sekunder yang mendukung penelitian.

2. Reduksi Data atau Klasifikasi data, adalah proses penelitian, pemusatan perhatian pada penyederhanaan data kasar dari catatan tertulis lapangan penelitian, membuat ringkasan, penggolongan kategori jawaban dan kualifasi jawaban informan penelitian kembali catatan yang telah diperoleh setelah mengumpulkan data. Peneliti mereduksi data setelah melakukan pengumpulan data, hal ini bertujuan untuk mendapatkan gambaran yang jelas mengenai hasil penelitian yang telah dilakukan peneliti selama dilapangan mengenai proses adaptasi yang dilakukan oleh kelompok Gambang Kromong di Betawi dalam mengatasi perkembangan dinamika dari Gambang Kromong asli menjadi gambang Kromong kombinasi. Sehingga hal ini memudahkan peneliti untuk melanjutkan analisa data pada tahap berikutnya.

3. Penyajian Data atau Analisis data, yakni penyusunan penyajian kategori jawaban informan dalam tabulasi serta gambar atau kecenderungan dari informan disertai analisis awal terhadap berbagai temuan data di lapangan sebagai proses awal dalam pengolahan data. Dengan mendisplay data, maka akan memudahkan untuk memahami dan peneliti menyusun data tersebut secara urut maka peneliti akan melakukan pengolahan data, sehingga apabila terdapat data yang tidak sesuai dengan kebutuhan penelitian, peneliti dapat mengedit data tersebut sehingga data tersebut sesuai dengan kebutuhan penelitian, pengeditan data tersebut bersifat memperbaiki data apabila terjadi kesalahan di dalam pengumpulan data, kesalahan pada data akan di perbaiki atau dilengkapi dengan melakukan pengumpulan data ulang atau dengan menyisipkan data yang kurang

4. Proses akhir penarikan kesimpulan, yaitu dilakukannya pembahasan yang berdasarkan pada rujukan berbagai teori yang digunakan dimana di dalamnya ditentukan suatu kepastian mengenai aspek teori dan kesesuaian atau ketidaksesuaian dengan fakta hasil penelitian di lapangan dimana peneliti juga membuat suatu analisis serta membuat tafsiran atas tampilan data sesuai dengan permakemudian ditarik kesimpulan dari penganalisaan data dan mendeskripsikan data tersebut sehingga data tersebut dapat di mengerti dan jelas.salahan penelitian

\section{Hasil dan Pembahasan}

Perubahan dalam penggunaan tangga nadanya dari lima nada (pentatonis) menjadi tujuh nada (diatonis) membuat suatu pemaksaan dalam peng ungkapan emosional lagu-lagu yang dibawakan. Tangga nada diatonis yang sudah mempunyai patokan (patron) yang jelas dalam pola permainannya 
memberikan karakter musik Gambang Kromong menjadi berubah.

Penampilan grup musik Gambang Kromong pada masyarakat tradisi sudah memasukkan bentuk lagu keroncong, pop, dan dangdut. Lagu-lagu tradisi seperti Cente Manis, Kramat Karem, Sirih Kuning, Jali-jali, dan lain-lain, tetap masih dipergunakan, walaupun sudah berkurang dalam pembawaannya. Lagu-lagu yang dibawakan merupakan suatu kesepakatan yang sudah dijalin oleh para pemainnya.

Pola penyajian musik Gambang Kromong dalam lingkungan masyarakat Betawi sangat komunikatif. Penonton dan pemusik dapat berinteraksi secara langsung tanpa ada pembatasan. Pola interaktif keduanya memberikan kesan bahwa musik dan penonton membawa suasana menjadi semarak. Lagu-lagu yang dibawakan oleh grup Gambang Kromong yang disajikan dalam masyarakat Betawi sebagian besar lagu tradisi. Permintaan lagu dari penikmatnya banyak memesan lagu-lagu tradisi seperti Sirih Kuning, Jali-jali, Cente Manis, Kramat Karem, dan lain-lain. Lagu tradisi Betawi dalam hal segi syairnya dapat digolongkan ke dalam jenis pantun yang tidak beraturan.

Setiap orang penyanyi yang membawakan sebuah lagu tradisi dapat melantunkan keanekaragaman syairnya walaupun jenis lagu yang dibawakan sama judulnya. Faktor utama yang dapat dikatakan bahwa seorang penyanyi tampak mahir apabila sudah menguasai dengan baik syairsyair lagu yang dinyanyikan. Penguasaan dengan baik dari syairnya merupakan ukuran dari kemahiran seorang penyanyi musik Gambang Kromong.

Jumlah birama yang dimainkan pada penyajian lagu tradisi Betawi disesuaikan dengan kemampuan penyanyi dalam membawakan pantun. Perubahan tempo yang terjadi dalam setiap penyajiannya menghilangkan rasa monoton pada waktu terjadi pengulangan lagu. Penyanyi membawakan pantun syair lagunya dengan mempergunakan bahasa dialek Betawi.

Tabuhan musik Gambang Kromong terbagi dalam dua golongan yaitu tabuhan ritmis dan tabuhan melodis. Alat musik tradisional yang termasuk dalam tabuhan ritmis ialah kecrek, ningnong, kempur, gendang, kempul, dan gong, sedangkan yang termasuk dalam tabuhan melodis ialah gambang, kromong, kongahyan, tebyan, sukong, jutao,dan basing (suling).

Transformasi yang terjadi dalam penggunaan alat musik Barat membuat perubahan pola tabuhan yang dipergunakan pada penyajiannya. Masuknya alat-alat musik Barat dalam penyajian musik Gambang Kromong mempengaruhi pola tabuhan yang dimainkan. Instrumen musik gambang, kromong, dan tehyan yang kerap kali dipergunakan untuk mengawali (introduksi) 
dalam sebuah lagu tergeser dengan adanya alat musik gitar dan terompet.

Jarak nada yang dimainkan oleh kedua instrument musik tersebut mengarah pada tangga nada diatonis. Penyanyi yang akan melantunkan sebuah lagu harus menyesuaikan dengan tangga nada yang dimainkan alat musik itu. Adapun contoh lagu yang terdapat dalam musik Gambang Kromong yang dituliskan dengan mempergunakan notasi angka adalah sebagai berikut:

$\mathrm{D}=\mathrm{Do}, 4 / 4$

Lagu Sirih Kuning

Ciptaan: NN.

Introduksi/Pembuka:

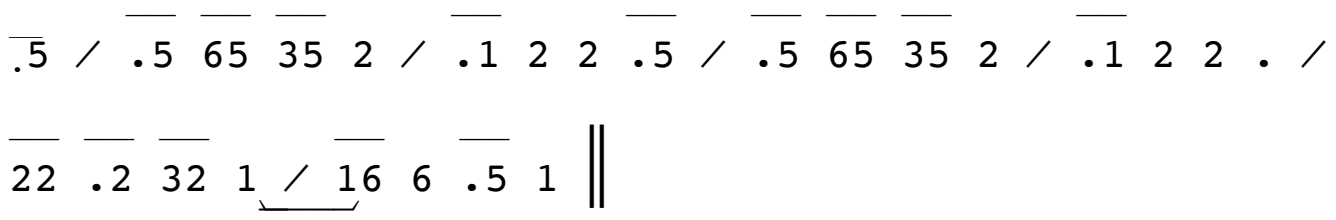

\section{Bagian A:}

$535 i / . \bar{i} \dot{2} \dot{3} . \bar{i} / \overline{.}$ i $65 / \overline{.5}$ i $5 \overline{.5} /$

Laju Laju Abang Pe- ra-hu Laju Sayang LaLupa Kaen Aduh Lu- pakan Baju Sayang Ja-

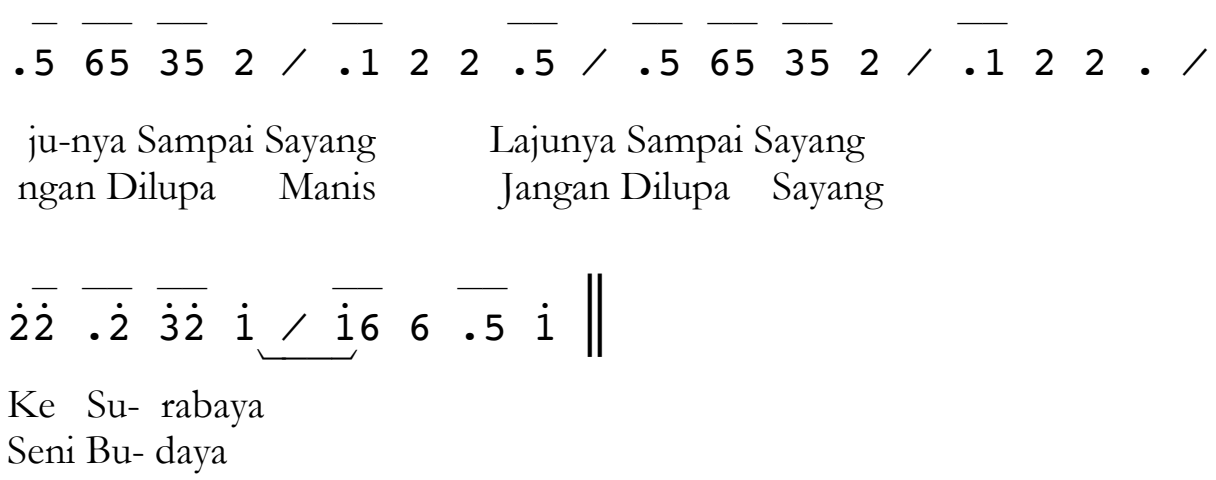




\section{Bagian B:}

3 2 i $6 / \overline{.6}$ i $6 . / 2$ i $65 / \overline{.5}$ i $5 \overline{.5} /$

Sirih Kuning Ya Sayang Nama Lagunya Sayang

Ala Sirih Kuning Ya Sayang Diatas Meja Ya Sayang

\section{$. \overline{5} \overline{65} \overline{35} 2 / \overline{.1} 22 \overline{.5} / \overline{.5} \overline{65} \overline{35} 2 / \overline{.1} 22 . /$}

Yang PutihKuning Ya Sayang Yang Putih Kuning Ya Nona

Yang Bajunya Kuning Ya Sayang Yang Bajunya Kuning Ya Sayang

$$
\dot{2} \overline{\dot{2}} \overline{.} \overline{\dot{3} \dot{2}} \dot{\mathrm{i}} / \overline{\mathrm{i} 6} 6 \overline{.5} \text { i }
$$

Siapa Namanya

Orangnya Manja

Pembawaan lagu Sirih Kuning disesuaikan dengan kemampuan seorang banyak mempergunakan gaya khas dari penyanyi dalam perbendaharaan kalimat musik Gambang Kromong. Karakter yang syairnya yang berbentuk pantun. Semakin menonjol dari teknik pengolahan vokalnya membuat suatu harmonisasi dengan pengiring musiknya. Syair yang dibawakan dapat diganti dengan kemampuan seorang penyanyi dalam perbendaharaan pantun yang dimilikinya. Pada setiap bagian (bagian A dan bagian B) diulang dan isian syairnya banyak perbendaharaan syair yang dilakukan oleh seorang penyanyi, maka hal itu menjadikan pembawaan lagunya akan lebih dinamis. Syair-syair yang dilantunkan dapat berisi pujian atau sanjungan, kritikan, ataupun sosialita yang terdapat dalam masyarakat.

$\mathrm{D}=\mathrm{Do}, 4 / 4$

Lagu Jali-jali

Ciptaan: NN

\section{Introduksi/Pembuka:}

$\|\overline{11} \overline{33} \overline{56} 6\|$

\section{Lagu Pokok:}

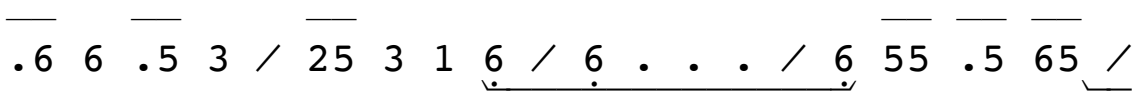


I- ni Di e Si Jali- ja- li Lagunya Enak

$5 \overline{5} \overline{55} \overline{65}, \overline{.3} \overline{53} 3 \underbrace{5 / 5} 1 \overline{11} \overline{.5} / \overline{55} \overline{11} \overline{21}$ 6 /

Lagunya Enak Merdu Sekali

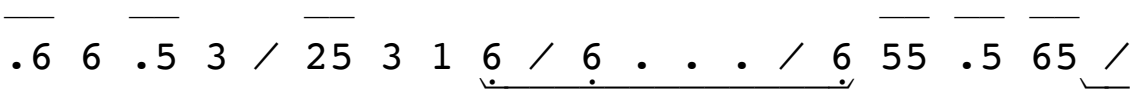

I- ni Di e Si Jali- ja- li Lagunya Enak

$5 \overline{5} \overline{55} \overline{65}, \overline{.3} \overline{53} 3 \underbrace{5 / 5} 1 \overline{11} \overline{.5} / \overline{55} \overline{11} \overline{12} \underbrace{3 /}$

Lagunya Enak Merdu Sekali

$3 \overline{55} \overline{.5} \overline{\mathrm{i} 6} / 6 \overline{.5} \overline{55} \overline{\mathrm{i} 6}, \overline{.5} \overline{55} \overline{.3} 5 / \overline{.3} 2 . . /$

Cape Sedikit Cape Sedikit Gak Perduli Sayang

2 $\overline{55} \overline{.5} \overline{53}, 3 \overline{5} \overline{53} \overline{23}, \overline{.1} \overline{11} \overline{53} 1,1 / 1 \overline{11} \overline{.5}$,

Asal kan Tuan Asal kan Tuan Senang di Hati

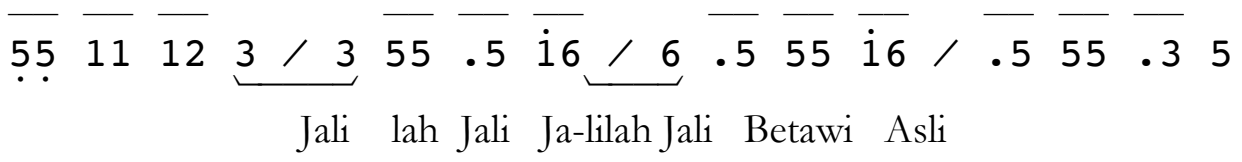

$\overline{3} 2 . . / 2 \overline{55} \overline{.5} \overline{53} / 3 \overline{5} \overline{53} \overline{23} / \overline{5} \overline{11} \overline{53} 1 \|$

Sayang Saya Menyanyi Saya Menyanyi Menghibur hati

Lagu jali-jali sudah sangat dikenal dalam sajian musik Gambang Kromong. Lagu ini menggambarkan suatu kiasan tentang kehidupan masyarakat Betawi. Dalam perkembangannya, lagu tersebut sudah semakin kurang diminati oleh masyarakat pendukungnya. Adanya lagu-lagu populer dalam masyarakat pendukung
Gambang Kromong mengakibatkan volume penyajian lagu khas Gambang Kromong tergeser kedudukannya. Gaya (style) yang dibawakan oleh para penyanyi dengan adanya lagu-lagu populer menjadikan lebih didominasi dengan olahan vokal diatonis. 


\section{Syair dan Penyanyi}

Karya sastra, termasuk puisi (syair) adalah sebuah struktur. Sebuah struktur menyiratkan adanya unsur pembentuk. Syair adalah sebuah struktur yang kompleks, yang terdiri atas unsur-unsur yang saling berjalinan dengan erat. Unsur-unsur itu tidak berdiri sendiri-sendiri. Sebuah unsur hanya mempunyai arti dalam kaitannya dengan unsur-unsur lainnya didalam struktur itu dan kaitannya dengan keseluruhannya. Unsur dalam struktur adalah unsur fungsional yaitu mempunyai tugas (fungsi) tertentu dalam menyusun struktur (Pradopo, 1997: 14).

Vokal musik Gambang kromong dikategorikan ke dalam genre sastra, maka analisis struktural dalam dunia sastra akan diterapkan disini. Maksudnya, analisis vokal Gambang Kromong dilakukan lewat pendekatan objektif, dimana musik Gambang Kromong didudukkan sebagai struktur yang bersifat otonom. Penggunan pendekatan interkstualitas akan dipergunakan dalam bahasannya. Seperti yang dijelaskan oleh A. Teeuw bahwa pendekatan intertekstualitas bertolak pada anggapan dasar bahwa sebuah karya sastra baru pasti mempunyai mata rantai dengan karya sastra sebelumnya. Hal tersebut diartikan karya sastra baru terkadang menyimpangi karya sastra yang lama dan bahkan merupakan transformasi darinya. Pendapat Teeuw itu berpijak pada pemikiran
Julia Kristeva yang merupakan pencetus pertamanya. Selain itu Jonathan Culler mengemukakan pula tentang intertekstualitas dalam bukunya Structualist Poetics: Structuralism, Linguistics and The Study Literature (1975) dan The Persuit of Sign: Semiotics, Literature, Deconstruction (1981) bahwa prinsip intertekstualitas harus sampai pada pembuktian bahwa karya sastra terdahulu memberikan kode-kode yang memungkinkan efek signifikan, sehingga melahirkan berbagai pemaknaan yang selaras ataupun penyimpangan dan pembaharuan. Jurij Lotman bahkan mengatakan pendekatan ini harus menghasilkan estetika persamaan dan estetika penyimpangan yang muncul sebagai pembeda kebudayaan, karena inilah akar intertekstualitas (A.Teeuw 1984, 3-7).

Menurut J. Culler karya sastra bukan suatu objek yang innoncent, tetapi merupakan interior terhadap karya sastra lainnya. Pandangan ini mengandung makna bahwa keorisinilitasan suatu karya sastra yang baru tidak merupakan masalah yang pokok dan penting, mengingat karya sastra baru hadir karena ada karya sastra sebelumnya (Culler, 1981: 2).

Karya sastra yang satu dapat menjadi interior bagi karya sastra yang lain yang lebih kemudian. Artinya antara karya sastra yang kemudian lahir bukan dari kekosongan melainkan lahir sebagai kesinambungan dari karya sastra yang ada lebih dahulu. 
Konsekuensinya setiap pembaca karya sastra harus berdasarkan pada karya-karya sastra lain atau sebelumnya yang dianggap setara dengan karya sastra yang dibaca tersebut. Secara tidak langsung teori-teori tersebut mengisyaratkan bahwa karya sastra yang kemudian mempunyai aspek penerimaan terhadap karya sastra yang sebelumnya dengan pengertian karya sastra ini memberi kemungkinan terhadap pengarang karya kemudian untuk menciptakan karya baru. Dalam pengertian yang demikian berarti di samping ada aspek penerimaan akan timbul pula suatu kesan dan makna tertentu yang menyebabkan adanya pengalaman baru, sehingga menghasilkan aspek ekuivalensi dan deviasi.

Menganalisis intertekstual dalam syair musik Gambang Kromong terlebih dahulu akan dilakukan analisis struktural. Analisis vokal musik Gambang Kromong akan dilakukan melalui pendekatan objektif, dimana strukturnya didudukkan sebagai struktur yang bersifat otonom. Bila mengacu pandangan dari Aristoteles bahwa suatu karya itu mempunyai keseluruhan (wholeness) karena karya itu mempunyai 4 (empat) unsur yang saling berkaitan dalam membentuk keseluruhan tersebut. Unsur itu meliputi urutan (order) yang teratur, kompleklsitas (complexity), kesatuan (unity), dan koherensi (coherence) yang saling terkait dan bersatu padu dengan harmonis (A. Teeuw, 1984: 120-139).
Urutan (order) menuntut keharusan adanya urutan demikian rupa sehinga menampilkan urutan-urutan unsur yang harmonis, sedang kompleksitas adalah penyajian suatu ruang lingkup yang dimungkinkan untuk menghadirkan perkembangan cerita yang utuh. Kesatuan (unity) adalah suatu urutan yang sedemikian rupa sehingga tidak adanya kesempatan untuk saling bertukar tempat diantara unsur-unsur tersebut, dan unsur koherensi dibuktikan oleh adanya pertalian erat dalam keseluruhan isi.

Syair musik Gambang Kromong adalah sebuah bentuk puisi yang tidak terikat dengan bentuk sanjaknya. Kemampuan dari setiap penyanyinya dalam mengolah syair yang dilantunkan merupakan kekuatan dari musik itu. Secara struktural dalam setiap bait terdiri dari 4 (empat) baris. Sesuai dengan alur pantun yang dinyanyikan, dalam baris pertama dan kedua merupakan sampiran, sedangkan baris ketiga dan keempat merupakan isinya. Seperti pada umumnya karya sastra lama yang lain, hubungan antara bait yang satu dengan bait yang lain tidaklah pekat, melainkan cenderung longgar. Oleh sebab itu dapat dimengerti bahwa alurnya juga tampak longgar dan cenderung kronologis. Tak ada nama pada setiap bait, baik itu nama jenis maupun nama yang berhubungan dengan judul lagunya.

Bait pertama dan bait kedua berisi sampiran dan bait ketiga dan bait keempat 
berisi tentang isi. Unsur-unsur tersebut di atas membentuk karya sastra genre puisi yang teruntai dalam musik Gambang Kromong. Oleh sebab itu pada dasarnya struktur vokal musik Gambang kromong mempunyai alur kronologis atau alur waktu, sebab setiap syair yang dinyanyikan mempunyai hubungan dengan pengalaman si penyanyinya sendiri. Hal ini tidak mengherankan sebab teks vokal tersebut berisi tentang kejadian atau permasalahan sosial yang sering dialami dalam kehidupan masyarakat Betawi. Isi yang dituangkan bisa terjadi suatu sindiran atau kritik sosial bagi masyarakatnya.

Karya sastra, termasuk puisi (syair) adalah sebuah struktur. Sebuah struktur menyiratkan adanya unsur pembentuk. Syair adalah sebuah struktur yang kompleks, yang terdiri atas unsur-unsur yang saling berjalinan dengan erat. Unsur-unsur itu tidak berdiri sendiri-sendiri. Sebuah unsur hanya mempunyai arti dalam kaitannya dengan unsur-unsur lainnya didalam struktur itu dan kaitannya dengan keseluruhannya. Unsur dalam struktur adalah unsur fungsional yaitu mempunyai tugas (fungsi) tertentu dalam menyusun struktur (Pradopo, 1997: 14).

Secara konvensional, bait syair terdiri atas 4 baris; tiap baris terdiri atas 2 periodus (Tiap baris sajak yang terdiri dari bagianbagian yang susunannya serupa). Periodus, yang terjalin dari bait awal sampai dengan bait akhir syair membentuk perioditas. Pada umumnya, tiap periodus terdiri dari 2 kata. Dalam pembahasan struktur formal syair Gambang Kromong, pertama-tama perhatian diarahkan pada lapis suara (sound stratum) dan lapis arti (units of meaning) karena kedua unsur tersebut merupakan sarana yang terpenting untuk memahaminya. Hal ini disebabkan karena sifat liris puisi. Oleh karena itu, satuan bunyi dan satuan arti merupakan sarana ekspresi yang utama (Pradopo, 1997: 57). Dengan demikian, pembahasan ini dilakukan karena karena erat kaitannya dengan sifat syair yang pada awal kehadirannya selalu disampaikan secara lisan.

Gaya bunyi meliputi penggunaan bunyi-bunyi tertentu untuk mendapatkan efek tertentu, yaitu efek estetis. Gaya bunyi merupakan gaya ulangan bunyi: asonansi, aliterasi, persajakan; sajak awal, sajak akhir, sajak dalam, dan sajak tengah. Kombinasi pola-pola bunyi itu membuat sajak menjadi merdu. Kombinasi bunyi yang merdu itu menimbulkan bunyi musik yang merdu dalam karya sastra, puisi pada khususnya. Orkestrasi yang berbunyi merdu disebut efoni (euphony) dan yang tidak berbunyi merdu (parau) disebut kakofoni (cacophony). Semua itu menimbulkan irama yang menyebabkan karya sastra liris, menimbulkan terjelmanya gambaran angan dan memperjelas makna sajak (Pradopo, 1997: 57). 
Dengan adanya irama (ada dua yaitu metrum dan ritme; metrum ialah irama yang konstan/ajeg karena oleh penggunaan bunyi yang tetap karena jumlah suku kata yang tetap dan polanya ajeg. Ritme ialah irama yang berdasarkan pergantian bunyi berturut-turut yang tidak ajeg, jumlah suku katanya atau katanya tidak tetap, hanya menjadi gema perasaan pengarangnya, selain syair terdengar merdu, mudah dibaca, juga hal ini menyebabkan aliran perasaan atau pikiran tidak terputus dan terkonsentrasi sehingga menimbulkan bayangan angan (imaji-imaji) yang jelas dan hidup. Hal ini juga menimbulkan adanya pesona atau daya magis sehingga melibatkan para pendengar kedalam keadaan extase (bersatu diri dengan objeknya) dan menyebabkan berkontemplasi hingga sajak itu dan apa yang dikemukakan meresap dalam hati, jiwa si pendengar (Pradopo, 1997: 44).

Jadi bunyi dalam syair berupaya merangsang kepekaan audien (pendengar) terhadap keindahan, nilai kemanusiaan, dan nilai-nilai ketuhanan yang dapat dirasakan oleh panca indera dan dikenali dengan jiwa atau hati. Dengan demikian, puisi berhubungan dengan kehidupan batin/rohani atau kejiwaan manusia. Puisi mempengaruhi kehidupan manusia lewat kehidupan batin dan kejiwaannnya. Lewat kehidupan kejiwaan ini, puisi mempengaruhi aktivitas kehidupan fisik.

Bunyi memiliki unsur asonansi dan aliterasi. Asonansi adalah ulangan bunyi vokal dalam baris sajak/syair. Asonansi ini disamping untuk kemerduan dan menimbulkan irama, juga untuk menyangatkan atau mengeraskan arti katakata atau untuk membangkitkan suasa tertentu. Hal ini berhubungan dengan simbolik bunyi atau lambang rasa (klanksymboliek). Aliterasi adalah ulangan konsonan dalam baris sajak (Pradopo, 1997: 58). Adapun salah satu contoh dari makna syair yang terkandung dalam lagu Sirih Kuning adalah sebagai berikut:

\author{
Laju-laju abang \\ Perahu laju sayang \\ Lajunya sampai sayang, lajunya sampai sayang \\ Ke Surabaya \\ Sirih kuning ya sayang \\ Nama lagunya sayang \\ Yang putih kuning ya sayang, yang putih kuning ya nona \\ Siapa Namanya
}


Periode yang pertama pada baris kesatu berisi asonansi (a-a dan $\mathrm{u}-\mathrm{u}$ ), yakni masing-masing berulang 2 dan 4 kali. Baris kedua berisi asonansi (e-e; a-a dan u-u), baris ketiga (a-a; u-u; i-i) terjadi pengulangan, dan baris keempat (a-a). Biasanya asonansi dikombinasikan dengan aliterasi seperti tampak pada kutipan di atas. Aliterasi atau sajak rangka adalah ulangan konsonan dalam baris sajak. Dalam baris satu ada aliterasi (j-j; 1-l; b-b), baris kedua (j-j; ny-ny), baris ketiga (d-d; h-h; n-n; g-g), dan baris keempat (s-s; bb). Periode yang kedua pada baris satu berisi asonansi (i-i dan a-a). Baris kedua berisi asonansi (a-a dan $\mathrm{u}-\mathrm{u})$, baris ketiga ( $\mathrm{a}-\mathrm{a}$; $\mathrm{u}-\mathrm{u}$; i-i) terjadi pengulangan, dan baris keempat (ii; a-a). Dalam baris kesatu ada aliterasi (h-h; n-n; ng-ng), baris kedua (n-n; m-m; ny-ny; ng$\mathrm{ng}$ ), baris ketiga (ng-ng; h-h; n-n), dan baris keempat (s-s; n-n; ny-ny). Kombinasi bunyibunyi vokal (asonansi) a; i ; u; e, bunyi-bunyi konsonan bersuara (voiced) d, g, p bunyi likuida: 1, dan bunyi sengau: $\mathrm{n}$, ny, ng menimbulkan bunyi merdu dan berirama (efoni). Bunyi yang merdu itu dapat mendukung suasana yang mesra, kasih sayang, dan bahagia. Dengan kommbinasi demikian, intensitas arti menjadi bertambah.

Dalam bait pertama, asonansi bunyi a berkombinasi dengan bunyi sengau serta konsonan bersuara dan bunyi likuida 1 menimbulkan bunyi yang merdu; begitu juga asonansi dalam bait kedua dan ketiga.
Adapun puncak rasa gembira, kasih sayang, dan bahagia terpancar dalam bait ketiga dengan bunyi yang merdu dan berirama dan liris (kombinasi asonansi, konsonan bersuara, dan bunyi sengau $\mathrm{m}, \mathrm{n}, \mathrm{ng}$ ) penuh curahan perasaan. Dengan demikan, terlihat jelas upaya yang dilakukan pengarang untuk menampilkan keindahan fisik yang tercermin pada kombinasi bunyi yang digunakan pada setiap lariknya. Melalui tampilan keindahan fisik ini diharapkan dapat menggugah minat pendengar untuk menghayati dan berkomunikasi dengan penyanyinya.

Gaya kiasan bunyi dalam sajak/puisi dapat berupa onomatope (tiruan bunyi, efeknya untuk mengkonkretkan gambaran angan), metafora bunyi (bunyi untuk mengiaskan bunyi yang sesungguhnya), dan simbolik bunyi. Simbolik bunyi dipergunakan bukan hanya sebagai orkestrasi untuk menimbulkan bunyi musik yang merdu, melainkan juga untuk membangun suasana atmosfer yang tercipta melalui komposisi bunyi yang terdapat dalam bait-bait syair. Simbolik bunyi disebut juga lambang rasa. Lambang rasa biasanya banyak dipergunakan oleh penyair dalam sajak-sajaknya. Lambang rasa biasanya juga dihubungkan dengan suasana hati. Suasana hati yang ringan, riang, dilukiskan dengan bunyi vocal a, i, u, e yang terasa ringan, dan kecil (Pradopo, 1997: 3233) 
Orkestrasi Bunyi yaitu kombinasi bunyi konsonan, vokal yang berturut-turut: asonansi dan aliterasi, pola sajak awal, tengah, dalam, dan akhir menimbulkan bunyi musik yang merdu dan berirama, kombinasi bunyi merdu disebut efoni (euphony). Kombinasi bunyi yang merdu biasanya dapat menimbulkan suasana menyenangkan dan rasa kasih sayang. Bunyi merdu ini berupa kombinasi bunyi sengau: $\mathrm{m}, \mathrm{n}, \mathrm{ng}$, ny; Bunyi bersuara (voiced) b, d, g; Bunyi likuida: 1 dan r. Kakofoni yaitu bunyi yang tidak merdu (parau). Berupa kombinasi bunyi tidak bersuara (unvoiced), berupa kombinasi bunyi k, p, t, s. Bunyi kakofoni ini memberikan suasana yang kacau balau, tidak menyenangkan (Pradopo, 1997: 62-63).

Alat untuk menyampaikan perasaan dan pikiran sastrawan adalah bahasa. Baik tidaknya tergantung kecakapan sastrawan dalam mempergunakan kata-kata. Oleh karena itu diperlukan penguasaan terhadap pengetahuan leksikografi dan kehalusan sastrawan dalam mempergunakan kata-kata tersebut menjadi syarat multak bagi sastrawan. Dengan demikian, tidak berarti bahwa bahasa dan kata-kata berbeda dengan bahasa masyarakat. Justru, puisi akan mempunyai nilai abadi bila sastrawan berhasil menggunakan kata-kata sehari-hari yang umum. Pemakaian bahasa daerah bukan untuk sekedar gagah-gagahan atau malah mempergelap arti melainkan untuk menimbulkan efek puitis. Begitu pula halnya penggunaan kata-kata asing harus dapat menimbulkan efek puitis. Jadi dalam konteks ini sangat dimungkinkan terjadinya gaya bahasa interferensi (penggunaan bahasa asing dalam bahasa sendiri/penggunaan bahasa campuran) dan gaya alih kode (penggunaan variasi bahasa lain untuk menyesuaikan diri dengan peran atau situasi lain atau adanya partisipasi lain yang menunjukan latar belakang budayanya sendiri (Pradopo, 1997: 51). Kedua gaya itu dipergunakan untuk mendapatkan efek lokal, nasional, dan universal dengan tetap mempertimbangkan efek estetis atau efek puitis karya.

Pemilihan kata (diksi) dipergunakan untuk mendapatkan arti (makna) setepattepatnya untuk intensitas pernyataan (ekspresi). Dikemukakan Barfield bahwa kata-kata dipilih setepat-tepatnya dengan cara sedemikian rupa hingga artinya menimbulkan imajinasi estetik, maka hasilnya itu disebut diksi puitik. Dengan kata lain, diksi dipergunakan oleh penyair agar ia dapat mencurahkan segenap perasaan dan isi pikirannya secara tepat. Selain itu, ia juga ingin mengekspresikan pengalaman jiwanya tersebut dengan pemilihan kata yang tepat. Jadi, diksi itu untuk mendapatkan kepuitisan dan untuk mendapatkan nilai estetik (Pradopo, 1997: 54). 


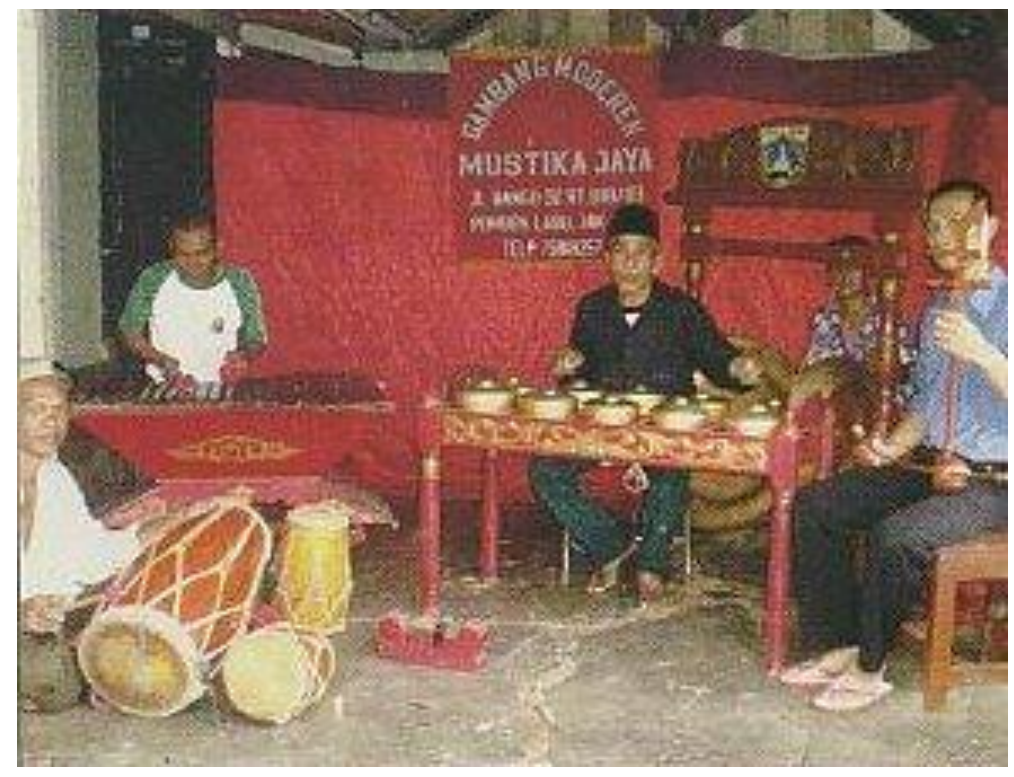

Gambar 3

Pertunjukan Gambang Kromong asli

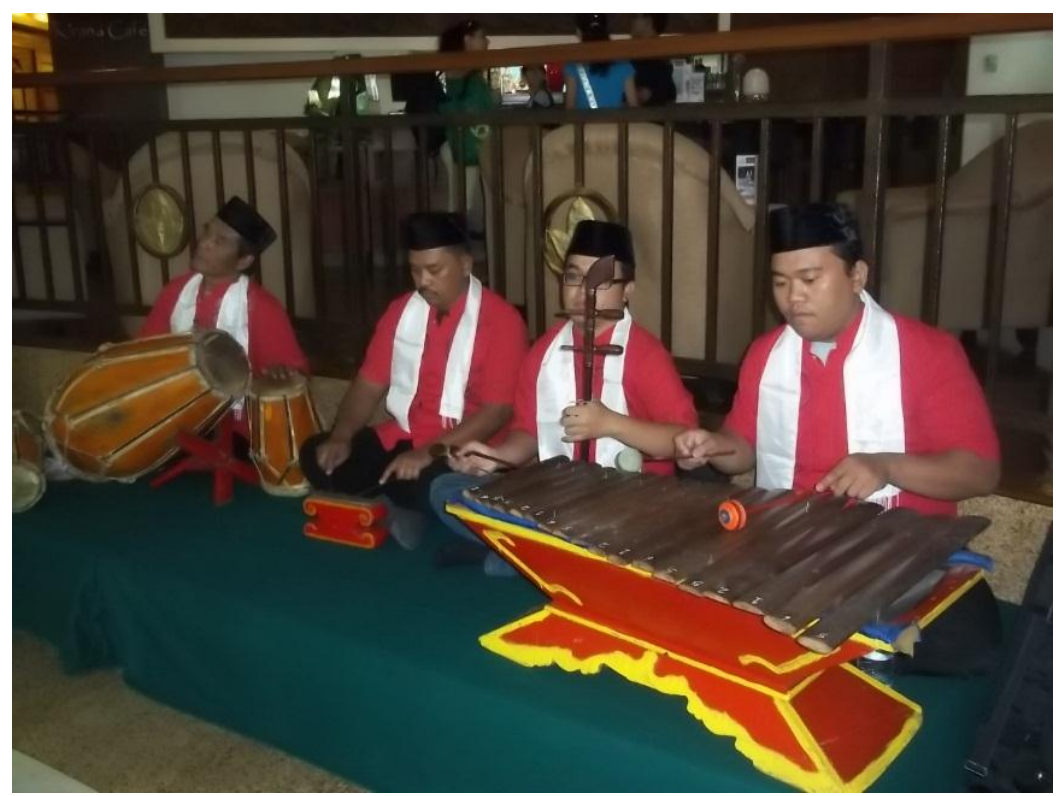

Gambar 4

Pertunjukan Gambang Kromong asli 


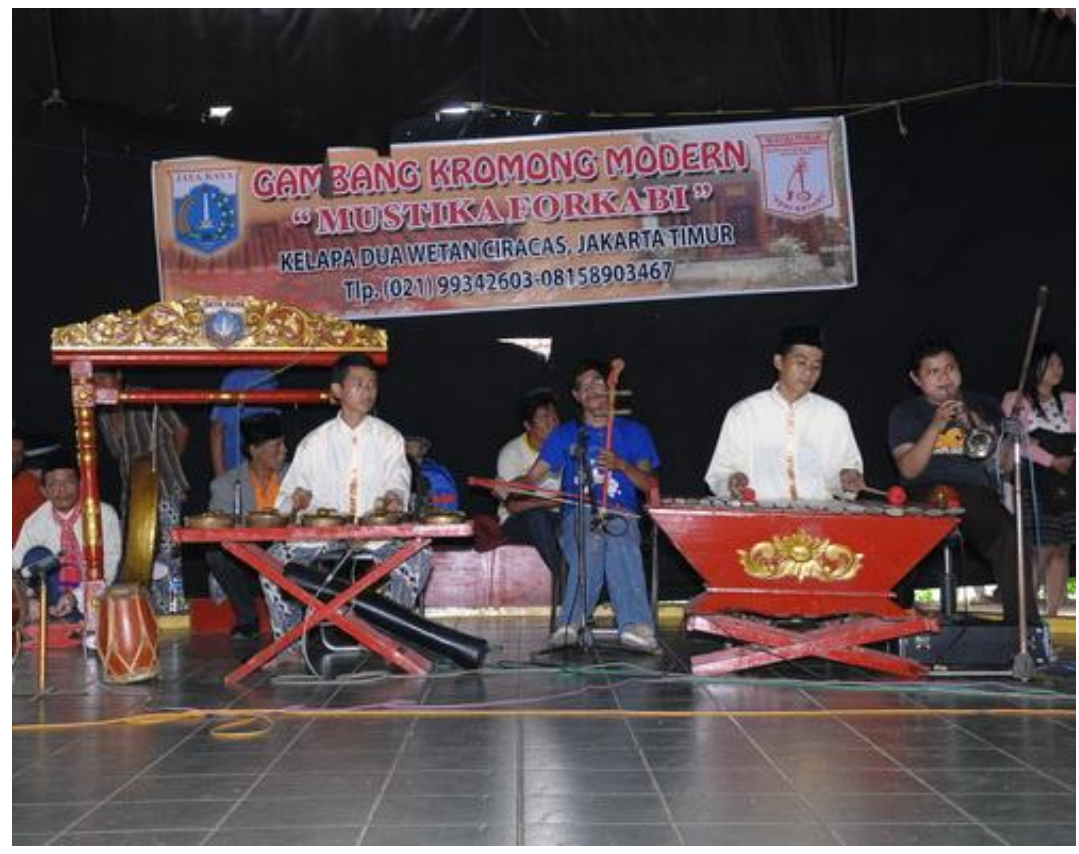

Gambar 5

Pertunjukan Gambang Kromong kombinasi

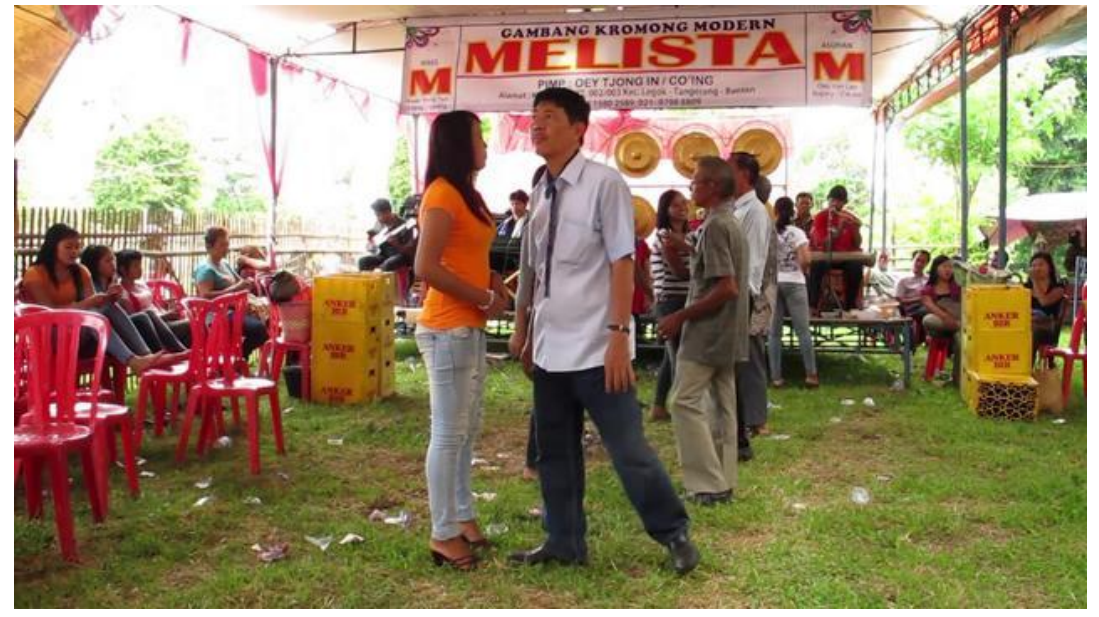

Gambar 6

Pertunjukan Gambang Kromong kombinasi 


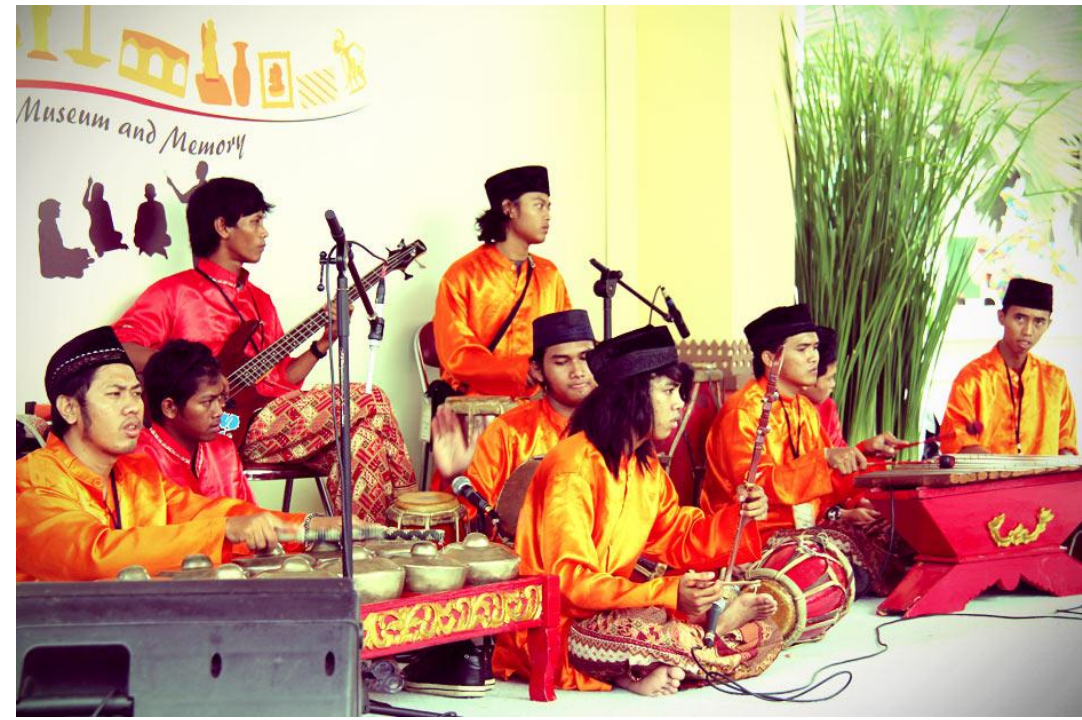

Gambar 7

Pertunjukan Gambang Kromong kombinasi

\section{Simpulan}

Suatu bentuk musik menggambarkan masyarakat menjadi nyata dalam kelompoknya. Musik sebagai realitas sosial mencakup aktivitas-aktivitas individu, musik, dan lain-lain. Pemberian ciri khas (perilaku mental) dalam aktivitas kesehariannya yang berhubungan dengan fakta-fakta musikal dapat diartikan bahwa perilaku musikal berhubungan antara manusia, antar personal atau sosial. Kesinambungan antara musik dan perilaku manusia menjadikan suatu hubungan yang saling kait mengkait antara keduanya. Musik menampakkan identitas masyarakatnya dan masyarakat tercermin dari bentuk musiknya.

Kota Jakarta sebagai ibukota negara Indonesia dan pusat kegiatan perekonomian yang mengarah pada pola kehidupan modern memberikan dinamika dalam kontinuitas kehidupan masyarakat Betawi. Penyesuaian dengan perkembangan zaman merupakan fenomena yang terjadi pada kelangsungan budaya masyarakatnya. Musik Gambang Kromong yang merupakan suatu bentuk kesenian masyarakat Betawi, kehidupannya semakin bersaing dengan masuknya budaya dari luar yang mewarnai kehidupan Jakarta. Persaingan yang demikian ketat mengakibatkan adanya stagnasi pada grupgrup Gambang Kromong.

Kemasan ensambel Gambang Kromong yang merupakan salinan dari bentuk aslinya, memasukan alat musik Barat dalam penyajiannya. Harapan yang diinginkan oleh senimannya dengan 
mempergunakan alat musik tersebut adalah agar dapat memainkan lagu pop, keroncong, dan dangdut. Selain itu musik ini dapat tampil dengan pandangan visual yang semakin modern. Pengaruh yang ditimbulkan dengan adanya hal tersebut yaitu semakin tergesernya pembawaan lagulagu tradisi Betawi. Pola tabuhan yang terjadi dalam ensambel musik Gambang Kromong untuk mengiringi lagu pop, keroncong, dan dangdut telah mengubah dari aturan-aturan tradisi yang berlaku. Lagu tradisi yang syair lagunya berjenis pantun dengan penekanan pada kemampuan penyanyi dalam mengolahnya, sudah berubah style (gaya) penyanyi dalam mengolah vokal dengan masuknya lagu pop, keroncong, dan dangdut.

\section{E. Daftar Pustaka}

Bogdan, Robert, and Steven J. Taylor, 1975. Introduction to Qualitative Research Methods, New York: John Wiley \& Sons.

Budiaman, et al., 1979, Folklor Betawi, Jakarta: Pustaka Jaya.

Castle, Lance, 1967, "The Ethnic Profile Djakarta", dalam Majalab Indonesia I, Djakarta.

Coopel, Charles A, 2002. Studying Ethnic Chinese in Indonesia, Singapore: Society of Asian Studies.
Creswell, John, 2011. Research Design Pendekatan Kualitatif, Kuantittatif, dan Mixed. Terj. Achmad Fawaid. Yogyakarta; Pustaka Pelajar

Danandjaja, James, 1988. Antropologi Psikologi: Teori, Metode dan Sejarah Perkembangannya.

Kaplan, David dan Manners Robert. 2002. Teori Budaya, Terjemahan Landung Simatupang: Yogyakarta. Pustaka Pelajar

Kayam, Umar, 1981, Seni, Tradisi, Masyarakat, Jakarta: Sinar Harapan.

Kian Sioe, Poa, Juni 1949, "Orkes Gambang Hasil Peranakan Tionghoa di Jakarta", dalam Majalab Pantja Warna, Jakarta.

Koentjaraningrat, 1982. Kebudayaan Mentalitas dan Pembangunan. Jakarta: PT. Gramedia Pustaka Utama

Koentaraningrat, $1986 . \quad$ Pengantar Antropologi, Jakarta: Aksara baru.

Koentjaraningrat, 1987. Sejarah Teori Antropologi. Jakarta: UI Press

Merriam, Alan P., 1964, The Anthropology of Music, Chicago: North Western University Press.

Moistoforoy, Zulkarnaen. 2002. Fieldwork Etnomusikologi 1. Surakarta: STSI Surakarta

Muljana, Slamet, 1980, Dari Holotan ke Jayakarta, Jakarta: Yayasan Idayu.

Muhadjir, et al., 1985, Peta Seni Budaya Betawi, Jakarta: Proyek Inventarisasidan Dokumentasi Kebudayaan Daerah. 
Nio Joe Lan, 1961. Peradaban Tionghoa Selayang Pandang, Djakarta: Keng Po.

Ohi, Rahmawati. 2014. Fungsi Bahasa pada bunyi Polopalo. Gorontalo. Jurnal Bahasa, Sastra dan Bahasa UNG hlm.189-194.

Parsudi Suparlan, 2004. Masyarakat dan Kebudayaan Perkotaan: Persfektif Antropologi Perkotaan, Jakarta:
Yayasan Pengembangan Kajian Ilmu Kepolisian.

Pradopo, Rachmat Djoko, 1997. Pengkajian Puisi, Yogyakarta: Gadjah Mada University Press.

Soedarsono, R.M., 2002, Seni Pertunjukan di Era Globalisasi, Yogyakarta: Gadjah Mada University Press.

Teeuw, A. 1984. Sastra dan Ilmu Sastra: Pengantar Ilmu Sastra, Jakarta: Pustaka Jaya. 